\title{
Clozapine in primary care
}

\section{SUMMARY}

Clozapine is the most effective antipsychotic, but is reserved for people with schizophrenia who have not adequately responded to two other antipsychotics. It has a high adverse event burden and requires close monitoring.

Whether prescribed by the hospital specialist or the GP, the GP will often be responsible for the monitoring of adverse effects and overall health of patients taking clozapine. All health professionals managing these patients must register with a clozapine monitoring service.

Serious adverse effects include neutropenia, agranulocytosis and myocarditis. Monitoring helps to prevent fatal outcomes.

Changes to the dose of clozapine, especially treatment interruptions, should be discussed with the patient's psychiatrist.

\section{Introduction}

Schizophrenia is defined as being treatment resistant if it leads to at least moderate impairment in functioning, and fails to respond to an adequate trial (six weeks with $>80 \%$ adherence) of two or more antipsychotic drugs at a dose equivalent to at least $600 \mathrm{mg}$ chlorpromazine daily. ${ }^{1}$ As many as one-third of patients with schizophrenia experience treatment resistance.

Clozapine is the most effective antipsychotic for reducing positive symptoms and hospitalisations among people with treatment-resistant schizophrenia. ${ }^{2-4}$ It should be used in combination with psychosocial therapies such as cognitive behavioural therapy (CBT) for psychosis, illness self-management training, and family support and education.

Clozapine was introduced in the 1960s but was withdrawn in the 1970s because it caused agranulocytosis. As better drugs for treatmentresistant schizophrenia did not emerge, clozapine was reintroduced with a strict scheme for neutrophil monitoring. Since clozapine was reintroduced in Australia in 1993, its use has steadily increased. ${ }^{5}$

Neutrophil monitoring has been so effective at minimising deaths due to agranulocytosis that in 2015 the US Food and Drug Administration recommended weakening the neutrophil cut-off for cessation of treatment to $1 \times 10^{9} / \mathrm{L}$ (currently $1.5 \times 10^{9} / \mathrm{L}$ in Australia, with increased monitoring below $2 \times 10^{9} / \mathrm{L}$ ). There have been calls to adopt these relaxed requirements in other countries. ${ }^{6}$ However, this should not lead to health professionals underestimating the importance of monitoring and managing adverse effects.

\section{Regulations}

Clozapine is usually first prescribed by a psychiatrist according to a treatment protocol. Some Australian states have allowed shared-care prescribing arrangements with GPs, but from 1 July 2015 GPs became eligible to prescribe maintenance clozapine without needing to be affiliated with a hospital. ${ }^{3}$ At the same time community pharmacies became eligible to dispense clozapine under the Pharmaceutical Benefits Scheme (PBS). ${ }^{3}$

Clozapine is listed as a section 100 'highly specialised' drug on the PBS.? Although GPs not affiliated with a hospital may prescribe maintenance clozapine under section 100, a review at least every six months by a specialist is prudent. Formal GP shared-care arrangements may offer less fragmented care. ${ }^{8}$

Treatment centres, individual patients, prescribers and pharmacists must also be registered with a clozapine patient monitoring system. Each brand of clozapine has its own monitoring service. There is usually a clozapine coordinator associated with each mental health service who links the hospital, GP, pharmacist, and the patient.

\section{Adverse effects and monitoring}

Clozapine is contraindicated in patients with bone marrow disorders and severe hepatic or renal impairment. Adverse effects can affect many systems (Table 1) so regular monitoring is required (Table 2), particularly at the start of treatment. The prescribing doctor should ensure that all members of the team are clear about who is responsible for monitoring the patient.

\section{Karl Winckel}

Senior pharmacist

Princess Alexandra Hospital

Conjoint lecturer

Pharmacy

University of Queensland

\section{Dan Siskind}

Psychiatrist

Metro South Addiction and

Mental Health Services

Brisbane

\section{Keywords}

adverse effects,

agranulocytosis, clozapine myocarditis, neutropenia, schizophrenia

Aust Prescr 2017:40:231-6 https://doi.org/10.18773/ austprescr.2017.067 


\section{Blood}

The risk of neutropenia and agranulocytosis is greatest in the first four months of therapy. Patients must have weekly full blood counts for the first 18 weeks of treatment and four-weekly full blood counts thereafter. These stringent monitoring requirements have significantly reduced the risk of death for these rare but serious adverse events.

\section{Cardiovascular}

Patients with schizophrenia suffer from higher rates of cardiovascular disease than the general population. This is often aggravated by a higher use of tobacco, poor diet, obesity, a sedentary lifestyle and the use of clozapine itself. ${ }^{9}$ Assessment of absolute cardiovascular risk with ongoing monitoring and risk reduction is required. Resources around monitoring ${ }^{10}$ and intervening" for cardiometabolic health are available.

\section{Table 1 Management of adverse effects of clozapine}

\begin{tabular}{|c|c|c|c|}
\hline Adverse effect & Frequency in patients & Usual time course & Management \\
\hline $\begin{array}{l}\text { Neutropenia/ } \\
\text { agranulocytosis }\end{array}$ & $\begin{array}{l}\text { Approximately } 2.7 \% \\
\text { (neutropenia) }\end{array}$ & First 18 weeks & Cease clozapine and send to hospital \\
\hline Myocarditis & $\begin{array}{l}\text { Widely variable but may be } \\
\text { anywhere up to } 1 \%\end{array}$ & First 4 weeks & Cease clozapine and send to hospital \\
\hline \multirow[t]{2}{*}{ Cardiomyopathy } & \multirow{2}{*}{$\begin{array}{l}\text { Estimated to be between } \\
1 \text { in } 1000 \text { and } 1 \text { in } 5000\end{array}$} & \multirow{2}{*}{$\begin{array}{l}\text { Any time, but more likely } \\
\text { with longer treatment } \\
\text { durations }\end{array}$} & Seek cardiologist diagnosis \\
\hline & & & Seek cardiologist and psychiatrist advice before cessation \\
\hline Tachycardia & Approximately $25 \%$ & First 4 weeks & Monitor for signs/symptoms of myocarditis \\
\hline \multirow[t]{2}{*}{ Fever } & \multirow[t]{2}{*}{ Varied } & \multirow[t]{2}{*}{ Varies depending on cause } & Urgent full blood count \\
\hline & & & Troponin if within the first 4 weeks of treatment \\
\hline \multirow[t]{4}{*}{ Seizures } & \multirow{4}{*}{$\begin{array}{l}0.9-29 \% \text { depending on dose, } \\
\text { patient, seizure subtype }\end{array}$} & \multirow[t]{4}{*}{ Any time } & Seek specialist advice \\
\hline & & & $\begin{array}{l}\text { Check clozapine dose and concentration, reducing } \\
\text { where possible }\end{array}$ \\
\hline & & & Ask about any recent attempts to quit smoking \\
\hline & & & Consider adding valproate or lamotrigine \\
\hline \multirow[t]{3}{*}{ Constipation } & \multirow[t]{3}{*}{$15-60 \%$} & \multirow[t]{3}{*}{ Any time } & Potentially life threatening \\
\hline & & & Treat and prevent aggressively \\
\hline & & & $\begin{array}{l}\text { Stool softeners, stimulants or osmotic laxatives may be } \\
\text { used first-line }\end{array}$ \\
\hline \multirow[t]{2}{*}{ Sedation } & \multirow[t]{2}{*}{$10-58 \%$} & \multirow{2}{*}{$\begin{array}{l}\text { Any time, but more common } \\
\text { in first few months }\end{array}$} & Adjust time of doses \\
\hline & & & Review other sedative drugs \\
\hline \multirow[t]{2}{*}{ Hypersalivation } & \multirow[t]{2}{*}{ Up to $30 \%$} & \multirow{2}{*}{$\begin{array}{l}\text { Any time, but more common } \\
\text { in first few months }\end{array}$} & First-line - non-pharmacological options \\
\hline & & & Second-line - sublingual anticholinergics \\
\hline \multirow[t]{2}{*}{ Postural hypotension } & \multirow[t]{2}{*}{ Approximately $10 \%$} & \multirow[t]{2}{*}{ First 4 weeks } & $\begin{array}{l}\text { First-line - ensure adequate fluid intake and advise patient } \\
\text { to sit up or stand slowly }\end{array}$ \\
\hline & & & $\begin{array}{l}\text { Second-line - low-dose fludrocortisone (starting dose } \\
100 \text { micrograms daily) }\end{array}$ \\
\hline \multirow[t]{3}{*}{ Weight gain } & \multirow{3}{*}{$\begin{array}{l}1 \text { in } 5 \text { patients will gain }>10 \% \\
\text { of their body weight } \\
\text { (average weight gain is } 8 \mathrm{~kg} \text { ) }\end{array}$} & \multirow[t]{3}{*}{ First year } & Advise on diet and exercise \\
\hline & & & Seek allied health input \\
\hline & & & Consider metformin controlled-release 1000 mg daily \\
\hline $\begin{array}{l}\text { Dyspepsia/gastro- } \\
\text { oesophageal reflux } \\
\text { disease }\end{array}$ & Approximately $20 \%$ & First 6 weeks & Consider proton pump inhibitor \\
\hline \multirow[t]{2}{*}{ Nocturnal enuresis } & \multirow[t]{2}{*}{ Approximately $20 \%$} & \multirow[t]{2}{*}{ Any time } & $\begin{array}{l}\text { Reduce caffeine and fluids late at night (ensure adequate } \\
\text { fluids during the day) }\end{array}$ \\
\hline & & & $\begin{array}{l}\text { Consider desmopressin nasal spray 10-20 micrograms } \\
\text { intranasally at night }\end{array}$ \\
\hline
\end{tabular}




\section{Chest pain, myocarditis and cardiomyopathy}

Chest pain requires careful consideration. Simple causes of chest pain such as gastro-oesophageal reflux disease are common in patients taking clozapine, however myocardial infarction, myocarditis and cardiomyopathy should be considered as differential diagnoses.

Myocarditis typically occurs in the first three weeks of therapy while cardiomyopathy occurs later in treatment (median nine months). ${ }^{12,13}$ Although rare (between 1 in 1000 and 1 in 5000) in short-term studies, in one retrospective Australian study of patients treated with clozapine and followed for 11 years, the incidence of cardiomyopathy was $4.65 \%(6 / 129) .^{13}$

Ceasing clozapine may have catastrophic consequences for some patients and care should be taken not to diagnose myocarditis without clinical investigations. ${ }^{14,15} \mathrm{~A}$ same-day review by an emergency department or cardiologist for ECG, troponin, chest X-ray and possible echocardiogram may be required. Myocarditis or cardiomyopathy should be confirmed by a cardiologist to avoid unnecessary cessation of clozapine.

\section{Tachycardia}

Tachycardia is common especially during the first four weeks of clozapine therapy. It is usually benign.12,13

\section{Postural hypotension}

Postural hypotension is common. Regular adequate fluid intake should be advocated, although specific advice to avoid sugary drinks is important. General advice around getting up slowly and leg muscle flexing is appropriate. Alcohol may worsen postural hypotension and the patient's intake should be assessed. In rare cases fludrocortisone may be required. ${ }^{12}$

\section{Gastrointestinal}

Nausea is a common and dose-related adverse effect of clozapine. ${ }^{12}$ Dyspepsia and reflux may be treated with proton pump inhibitors. Although variations in clozapine concentrations have been reported with omeprazole, ${ }^{16-18}$ all proton pump inhibitors are generally considered to be safe to use in patients taking clozapine.

\section{Constipation}

The prevalence of constipation is up to $60 \% .^{19}$ Severe untreated constipation may cause a fatal bowel obstruction. ${ }^{20-22}$ Red flag signs and symptoms include abdominal pain, distension, vomiting, overflow diarrhoea, absent bowel sounds and signs or symptoms of sepsis. ${ }^{12}$
Concomitant drugs with significant anticholinergic effects such as oxybutynin, and amitriptyline should be avoided when possible. Preventative aperients should be started at the first sign of constipation. A regular intake of sugar-free fluid should be recommended to all patients especially those prescribed increased dietary fibre. Regular exercise is also recommended. When intestinal obstruction has been excluded, a stimulant and softener combination such as docusate with senna may be used.12 The literature suggests that stimulant laxatives such as senna are not harmful to the colon, although this does not include studies of patients taking clozapine. ${ }^{23,24}$

\section{Metabolic}

After starting treatment a weight gain of over $10 \mathrm{~kg}$ is common and may continue for a year or longer. Half of the patients taking clozapine will develop metabolic syndrome and type 2 diabetes. ${ }^{12}$ Dietary modification and exercise may have significant positive effects on weight if patients can adhere to these regimens.

Metformin is an underused, evidence-based intervention for weight loss that is both safe and effective in patients without glucose intolerance or diabetes. ${ }^{9}$ On average there is a $3.1 \mathrm{~kg}$ weight loss, ${ }^{12}$ but metformin may cause a vitamin $\mathrm{B}_{12}$ deficiency so $B_{12}$ concentrations should be checked.

Dsylipidaemia and hyperglycaemia may occur with or without weight gain. ${ }^{12}$ Metformin is the recommended first-line treatment for hyperglycaemia. ${ }^{12}$ Patients with dyslipidaemia should be treated in the same way as other patients. Statins should be used for patients who meet the clinical criteria for their prescription.

\section{Fever}

Fever, cold and flu-like symptoms due to viral upper respiratory tract infections are common in the community, including in patients taking clozapine. In most cases these symptoms do not require adjustment of therapy. However, because these signs and symptoms may indicate myocarditis or secondary infections due to neutropenia, these conditions should be ruled out. Urgent full blood counts should be ordered.

\section{Sedation}

Sedation is a common and troubling adverse effect. Many patients sleep 10-12 hours per night. While shifting doses to night-time may reduce afternoon sedation, it can increase morning tiredness. The dosing schedule should be negotiated with patients. Treatment augmentation with drugs such as aripiprazole may help to reduce the required clozapine dose. This can reduce sedation, but should not be prescribed without consultation with a psychiatrist. ${ }^{12}$ 


\section{Table 2 Monitoring during clozapine treatment}

\begin{tabular}{|c|c|c|c|c|}
\hline Test & Frequency & Reason & What to do if abnormal & Comments \\
\hline $\begin{array}{l}\text { Weight/ } \\
\text { BMI/waist } \\
\text { circumference }\end{array}$ & Each GP visit & $\begin{array}{l}\text { Clozapine may cause ongoing and } \\
\text { profound weight gain }\end{array}$ & $\begin{array}{l}\text { Give lifestyle advice } \\
\text { Refer to allied health } \\
\text { Consider metformin }\end{array}$ & $\begin{array}{l}\text { Metformin is an underused } \\
\text { option to reduce weight } \\
\text { gain with clozapine }\end{array}$ \\
\hline Temperature & $\begin{array}{l}\text { Daily for first } \\
3 \text { weeks, then advise } \\
\text { patient to monitor }\end{array}$ & $\begin{array}{l}\text { May indicate myocarditis (if early in } \\
\text { therapy) or infection secondary to } \\
\text { neutropenia }\end{array}$ & $\begin{array}{l}\text { Screen for myocarditis if in the } \\
\text { first } 4 \text { weeks of therapy } \\
\text { Check full blood count }\end{array}$ & $\begin{array}{l}\text { Raised temperature may } \\
\text { occur in the first few weeks } \\
\text { of treatment }\end{array}$ \\
\hline $\begin{array}{l}\text { Pulse/blood } \\
\text { pressure }\end{array}$ & $\begin{array}{l}\text { Daily if possible for } \\
\text { first } 3 \text { weeks then } \\
\text { at each GP visit } \\
\text { thereafter }\end{array}$ & $\begin{array}{l}\text { Tachycardia is common with clozapine, } \\
\text { especially on initiation. However, } \\
\text { tachycardia may indicate myocarditis. } \\
\text { Initial hypotension may occur, but } \\
\text { long-term hypertension may occur as a } \\
\text { consequence of weight gain }\end{array}$ & $\begin{array}{l}\text { If there is tachycardia in first } \\
4 \text { weeks, screen for myocarditis } \\
\text { Beta blockers may be used } \\
\text { where clinically indicated } \\
\text { Hypotension may respond to } \\
\text { dividing the clozapine dose }\end{array}$ & $\begin{array}{l}\text { Long-term tachycardia } \\
\text { is a risk factor for } \\
\text { cardiomyopathy }\end{array}$ \\
\hline $\begin{array}{l}\text { Bowel motions/ } \\
\text { constipation }\end{array}$ & Each GP visit & $\begin{array}{l}\text { Deaths have occurred due to } \\
\text { clozapine-induced faecal impaction/ } \\
\text { bowel obstruction }\end{array}$ & $\begin{array}{l}\text { Stool softeners, stimulants, or } \\
\text { osmotic laxatives may be used } \\
\text { first-line }\end{array}$ & $\begin{array}{l}\text { Treat aggressively and } \\
\text { early }\end{array}$ \\
\hline $\begin{array}{l}\text { Cardiovascular } \\
\text { risk assessment }\end{array}$ & 6-monthly & Clozapine increases cardiovascular risk & Treat as appropriate & - \\
\hline Fasting glucose & 6-monthly & Clozapine may cause hyperglycaemia & $\begin{array}{l}\text { Advise on diet and exercise } \\
\text { Start metformin }\end{array}$ & - \\
\hline $\begin{array}{l}\text { White blood } \\
\text { cell count }\end{array}$ & $\begin{array}{l}\text { Every week for } 18 \\
\text { weeks then } 4 \text {-weekly }\end{array}$ & $\begin{array}{l}\text { Clozapine may cause neutropenia/ } \\
\text { agranulocytosis }\end{array}$ & $\begin{array}{l}\text { Discuss with clozapine } \\
\text { monitoring service and } \\
\text { psychiatrist }\end{array}$ & $\begin{array}{l}\text { If neutrophils below } \\
1.5 \times 10^{9} / \mathrm{L} \text {, cease clozapine } \\
\text { If between } 1.5 \text { and } \\
2 \times 10^{9} / \mathrm{L} \text {, increase } \\
\text { frequency of monitoring }\end{array}$ \\
\hline Lipids & 6-monthly & Clozapine may cause dyslipidaemia & $\begin{array}{l}\text { Advise on diet } \\
\text { Start statins for raised low- } \\
\text { density lipoprotein } \\
\text { Advise on alcohol reduction } \\
\text { for raised triglycerides }\end{array}$ & - \\
\hline $\begin{array}{l}\text { Clozapine } \\
\text { concentration }\end{array}$ & $\begin{array}{l}\text { 6-monthly and extra } \\
\text { measurements if } \\
\text { quitting smoking or } \\
\text { starting interacting } \\
\text { drugs }\end{array}$ & $\begin{array}{l}\text { Tobacco and other drugs may have } \\
\text { interactions } \\
\text { Low concentrations may indicate } \\
\text { non-compliance } \\
\text { Concentrations }>600 \text { micrograms/L } \\
\text { may increase seizure risk and } \\
>1000 \text { micrograms/L are considered } \\
\text { high risk for seizures }\end{array}$ & $\begin{array}{l}\text { Discuss with psychiatrist } \\
\text { before adjusting dose }\end{array}$ & $\begin{array}{l}\text { Measure trough } \\
\text { concentration }\end{array}$ \\
\hline Troponin & $\begin{array}{l}\text { Weekly for first } \\
4 \text { weeks }\end{array}$ & May help to identify myocarditis & $\begin{array}{l}\text { Screen for myocarditis if in } \\
\text { first } 4 \text { weeks of therapy } \\
\text { Consult with psychiatrist } \\
\text { before cessation }\end{array}$ & $\begin{array}{l}\text { The diagnosis of } \\
\text { myocarditis requires more } \\
\text { evidence than a positive } \\
\text { troponin }\end{array}$ \\
\hline $\begin{array}{l}\text { C-reactive } \\
\text { protein }\end{array}$ & $\begin{array}{l}\text { Weekly for first } \\
4 \text { weeks }\end{array}$ & May help to identify myocarditis & $\begin{array}{l}\text { Screen for myocarditis if in } \\
\text { first } 4 \text { weeks of therapy }\end{array}$ & - \\
\hline Echocardiogram & $\begin{array}{l}\text { Baseline and then } \\
\text { annually }\end{array}$ & May identify cardiomyopathy & $\begin{array}{l}\text { Refer to cardiologist and consult } \\
\text { with psychiatrist before cessation }\end{array}$ & - \\
\hline ECG & $\begin{array}{l}\text { 6-12 monthly (more } \\
\text { frequently during } \\
\text { initiation) }\end{array}$ & $\begin{array}{l}\text { There are ECG changes in both } \\
\text { myocarditis and cardiomyopathy but } \\
\text { ECG will also show QTc prolongation } \\
\text { and consequent risk of ventricular } \\
\text { arrhythmias }\end{array}$ & Refer to cardiology & $\begin{array}{l}\text { ECGs are less useful } \\
\text { than echocardiograms at } \\
\text { identifying cardiomyopathy } \\
\text { and do not replace need for } \\
\text { regular echocardiograms }\end{array}$ \\
\hline
\end{tabular}




\section{Hypersalivation}

Hypersalivation, particularly while sleeping, is a troublesome adverse effect that may embarrass and stigmatise patients. Sucking sugar-free lozenges may help to remind patients to swallow saliva. Absorbent pillow slips and placing a towel over the pillow at night may also help. Sublingual anticholinergic drugs have also been used to some effect. Drugs that have been tried include:12

- atropine eye drops either used sublingually directly or as a mouthwash (2 drops in $10 \mathrm{~mL}$ water)

- hyoscine hydrobromide tablets 300 micrograms sucked or chewed up to three times a day (systemic absorption is possible and may potentially cause or aggravate tachycardia, constipation or confusion)

- $\quad$ ipratropium metered dose inhaler 1-2 sprays up to three times a day sublingually.

\section{Seizures}

Clozapine has been associated with seizures with a cumulative one-year risk of approximately $2.9-5 \% .^{25,26}$ Seizures include a wide variety of epileptic activity and not just generalised tonic-clonic seizures.

The risk is increased in patients with serum clozapine concentrations greater than 1000 nanograms $/ \mathrm{mL}^{12,25-28}$ Reducing the intake of alcohol may reduce the risk. Immediate referral to an emergency department is indicated for patients who have a seizure while taking clozapine. Clozapine concentrations, testing for illicit drugs, brain imaging and a neurology review may be required. An accurate diagnosis of seizures is essential before considering stopping clozapine. It may be in the best interests of the patient to continue taking clozapine with the addition of an antiepileptic drug such as sodium valproate or lamotrigine. 12,27,28 The patient's psychiatrist should be consulted before any changes.

\section{Nocturnal enuresis}

Nocturnal enuresis affects up to one in five patients. ${ }^{29}$ Non-drug treatments are first-line and include:

- bladder training (physiotherapists may help with this)

- reducing caffeine intake

- reducing night-time fluids (but not total daily fluid intake)

- planned night-time wakening to urinate.

Continence pads and sheet protectors may be used if these methods are ineffective. In resistant cases desmopressin nasal spray (10-20 micrograms at night) may be used under specialist advice, although it is not listed on the PBS for this indication, and hyponatraemia may result.12,30

\section{Smoking and other cytochrome P450 inducers and inhibitors}

Brief interventions to encourage smoking cessation are appropriate in patients taking clozapine and GPs are in an ideal position to facilitate these. However, clozapine metabolism is accelerated by the non-nicotine components of tobacco which induce cytochrome P450 (CYP) 1A2 enzymes. Smoking cessation is therefore likely to significantly increase clozapine concentrations. Careful monitoring of clozapine concentrations is required during attempts to quit, and any planned change in dose should occur in consultation with a psychiatrist. ${ }^{12,31,32}$ Nicotine patches do not affect clozapine metabolism.

Carbamazepine is a CYP1A2 inducer and fluvoxamine is a CYP1A2 inhibitor so they are not advised in patients taking clozapine. Carbamazepine also should be avoided with clozapine therapy due to the additive risk of neutropenia. Drugs metabolised by CYP2D6 such as fluoxetine can increase clozapine levels so should not be prescribed to patients taking clozapine.

\section{Strategies to improve adherence}

Multifaceted interventions to improve adherence may include dose administration aids (e.g. Webster-pak), phone alarms, and direct monitoring of medicationtaking by carers. Clozapine coordinators and case managers can help identify non-government organisations that may offer a monitoring service. Individual or group education from clozapine coordinators and pharmacists is also recommended.

\section{Treatment interruptions}

Abrupt withdrawal of clozapine should be avoided as it may cause cholinergic rebound and acute psychosis.

Treatment interruptions for more than 48 hours, for example because of non-adherence, require an increase in the frequency of blood tests to weekly (if patients are having monthly blood tests). If the treatment interruption lasts more than 72 hours, re-titration of the clozapine dose is required. Failure to re-titrate causes an unacceptably high risk of seizures, severe hypotension, and coma. ${ }^{12}$ The patient's regular clozapine monitoring service and psychiatrist should be contacted.

\section{Therapeutic drug monitoring}

Clozapine concentrations are measured in trough samples and most studies show that the threshold for response is 350-600 micrograms/L.12 Concentrations of the main metabolite, norclozapine, are routinely reported with clozapine concentrations, but its importance for therapeutic efficacy is uncertain. 


\section{SELF-TEST}

\section{QUESTIONS}

True or false?

3. Dry mouth is a common adverse effect of clozapine.

4. The dose of clozapine may need to be reduced if the patient stops smoking.

Answers on page 247

\section{Shared care}

GPs are well placed to provide ongoing care for people taking clozapine. Essential components of GP shared-care programs include agreed monitoring protocols, and agreed prescribing responsibilities for prophylaxis and treatment of any clozapine-related adverse effects. Close communication between clozapine coordinators, GPs and patients is essential for monitoring and management of patients' adverse effects and for ensuring that the patients are attending their GPs.

\section{Conclusion}

Clozapine is a highly effective drug for treatmentresistant schizophrenia, however careful monitoring for, and accurate diagnosis of, clozapine-related adverse effects is essential. Therapeutic interventions to treat adverse effects are underused yet may significantly improve the quality of life of patients. Good communication between specialists, GPs and pharmacists is essential for the safe use of clozapine. $<$

Conflict of interest: none declared

\section{REFERENCES}

1. Howes O, McCutcheon R, Agid O, de Bartolomeis A, van Beveren NJ, Birnbaum ML, et al. Treatment-resistant schizophrenia: Treatment Response and Resistance in Psychosis (TRIPP) working group consensus guidelines on diagnosis and terminology. Am J Psychiatry 2017;174:216-29. https://doi.org/10.1176/appi.ajp.2016.16050503

2. Siskind D, McCartney L, Goldschlager R, Kisely S. Clozapine versus first and second-generation antipsychotics in treatment refractory schizophrenia: systematic review \& meta-analysis. Br J Psychiatry 2016;209:385-92. https://doi.org/10.1192/bjp.bp.115.177261

3. New supply arrangements for some S100 medicines. RADAR 2015 Sep 30. https://www.nps.org.au/radar/articles/new-supply-arrangements-for-somes100-medicines [cited 2017 Nov 1]

4. Samara MT, Dold M, Gianatsi M, Nikolakopoulou A, Helfer B, Salanti G, et al. Efficacy, acceptability, and tolerability of antipsychotics in treatment-resistant schizophrenia: a network meta-analysis. JAMA Psychiatry 2016;73:199-210. https://doi.org/10.1001/jamapsychiatry.2015.2955

5. Forrester T, Siskind D, Winckel K, Wheeler A, Hollingworth S. Increasing clozapine dispensing trends in Queensland, Australia 2004-2013. Pharmacopsychiatry 2015;48:164-9. https://doi.org/10.1055/s-0035-1554713

6. Bastiampillai T, Gupta A, Allison S. FDA changes clozapine monitoring guidelines: Implications for worldwide practice. Asian J Psychiatr 2016;21:19-20. https://doi.org/10.1016/j.ajp.2016.01.012

7. Australian Government Department of Health. The Pharmaceutical Benefits Scheme. Section 100 - Highly specialised drug program. http://www.pbs.gov.au/info/browse/section-100/s100-highly-specialiseddrugs [cited 2017 Nov 1]

8. Filia SL, Wheelhouse A, Lee SJ, Main M, de Castella A, Wilkins S, et al. Transitioning patients taking clozapine from the public to private/GP sharedcare setting: barriers and criteria. Aust N Z J Psychiatry 2012;46:225-31. https://doi.org/10.1177/0004867411433210

9. Siskind DJ, Leung J, Russell AW, Wysoczanski D, Kisely S. Metformin for clozapine associated obesity: a systematic review and meta-analysis. PLoS One 2016;11:e0156208. https://doi.org/10.1371/journal.pone.0156208

10. Positive cardiometabolic health resource: an intervention framework for people experiencing psychosis and schizophrenia. Lester UK Adaptation. 2014 update. http://www.rcpsych.ac.uk/quality/nationalclinicalaudits/ schizophrenia/nationalschizophreniaaudit/nasresources.aspx\#CMH [cited 2017 Nov 1]

11. Waterreus AJ, Laugharne J. Screening for the metabolic syndrome in patients receiving antipsychotic treatment: a proposed algorithm. Med J Aust 2009;190:185-9.

12. Taylor D, Paton C, Kapur S. The Maudsley prescribing guidelines in psychiatry. 12th ed. Hoboken: Wiley Blackwell; 2015.

13. Leo RJ, Kreeger JL, Kim KY. Cardiomyopathy associated with clozapine. Ann Pharmacother 1996;30:603-5. https://doi.org/10.1177/106002809603000606

14. Ronaldson KJ, Taylor AJ, Fitzgerald PB, Topliss DJ, Elsik M, McNeil JJ. Diagnostic characteristics of clozapine-induced myocarditis identified by an analysis of 38 cases and 47 controls. J Clin Psychiatry 2010;71:976-81. https://doi.org/10.4088/JCP.09m05024yel

15. Winckel K, Siskind D, Hollingworth S, Wheeler A. Clozapine-induced myocarditis: separating the wheat from the chaff. Aust N Z J Psychiatry 2015;49:188. https://doi.org/10.1177/0004867414554269
16. Wagner S, Varet-Legros MG, Fabre C, Montastruc JL, Bagheri H. Confounding factors for variation of clozapine plasma levels: drug interactions with proton pump inhibitor or infectious etiologies? Eur J Clin Pharmacol 2011;67:533-4. https://doi.org/10.1007/s00228-010-0925-z

17. Mookhoek EJ, Loonen AJ. Retrospective evaluation of the effect of omeprazole on clozapine metabolism. Pharm World Sci 2004;26:180-2. https://doi.org/10.1023/B:PHAR.0000026808.97403.05

18. Frick A, Kopitz J, Bergemann N. Omeprazole reduces clozapine plasma concentrations. A case report. Pharmacopsychiatry 2003;36:121-3. https://doi.org/10.1055/s-2003-39980

19. Hayes G, Gibler B. Clozapine-induced constipation. Am J Psychiatry 1995;152:298a. https://doi.org/10.1176/ajp.152.2.298a

20. De Hert M, Hudyana H, Dockx L, Bernagie C, Sweers K, Tack J, et al. Second-generation antipsychotics and constipation: a review of the literature. Eur Psychiatry 2011;26:34-44. https://doi.org/10.1016/j.eurpsy.2010.03.003

21. Cohen D, Bogers JP, van Dijk D, Bakker B, Schulte PF. Beyond white blood cell monitoring: screening in the initial phase of clozapine therapy. J Clin Psychiatry 2012;73:1307-12. https://doi.org/10.4088/JCP.11r06977

22. Palmer SE, McLean RM, Ellis PM, Harrison-Woolrych M. Life threatening clozapine-induced gastrointestinal hypomotility: an analysis of 102 cases. J Clin Psychiatry 2008;69:759-68. https://doi.org/10.4088/JCP.v69n0509

23. Müller-Lissner SA, Kamm MA, Scarpignato C, Wald A. Myths and misconceptions about chronic constipation. Am J Gastroenterol 2005;100:232-42. https://doi.org/10.1111/j.1572-0241.2005.40885.x

24. Wald $A$. Is chronic use of stimulant laxatives harmful to the colon? J Clin Gastroenterol 2003;36:386-9. https://doi.org/10.1097/ 00004836-200305000-00004

25. Williams AM, Park SH. Seizure associated with clozapine: incidence, aetiology, and management. CNS Drugs 2015;29:101-11. https://doi.org/10.1007/ s40263-014-0222-y

26. Devinsky O, Honiqfeld G, Patin J. Clozapine-related seizures. Neurology 1991;41:369-71. https://doi.org/10.1212/WNL.41.3.369

27. Varma S, Bishara D, Besaq F, Taylor D. Clozapine-related EEG changes and seizures: dose and plasma-level relationships. Ther Adv Psychopharmacol 2011;1:47-66. https://doi.org/10.1177/2045125311405566

28. Caetano D. Use of anticonvulsants as prophylaxis for seizures in patients on clozapine. Australas Psychiatry 2014;22:78-82. https://doi.org/10.1177/ 1039856213502829

29. Harrison-Woolrych M, Skegg K, Ashton J, Herbison P, Skegg DC. Nocturnal enuresis in patients taking clozapine, risperidone, olanzapine, and quetiapine: comparative cohort study. Br J Psychiatry 2011;199:140-4. https://doi.org/ 10.1192/bjp.bp.110.087478

30. Steingard S. Use of desmopressin to treat clozapine-induced nocturnal enuresis. J Clin Psychiatry 1994;55:315-6.

31. Rüther T, Bobes J, de Hert M, Svensson TH, Mann K, Batra A, et al. EPA guidance on tobacco dependence and strategies for smoking cessation in people with mental illness. Eur Psychiatry 2014;29:65-82. https://doi.org/ 10.1016/j.eurpsy.2013.11.002

32. Cormac I, Brown A, Creasey S, Ferriter M, Huckstep B. A retrospective evaluation of the impact of total smoking cessation on psychiatric inpatients taking clozapine. Acta Psychiatr Scand 2010;121:393-7. https://doi.org/10.1111/ j.1600-0447.2009.01482.x 